\title{
DIFFERENTIATION OF UTRICULARIA OCHROLEUCA AND U. STYGIA POPULATIONS IN TřEBOŇ BASIN, CZECH REPUBLIC, ON THE BASIS OF QUADRIFID GLANDS
}

BARTOSZ J. PŁACHNO $\bullet$ Institute of Botany $\bullet$ Department of Plant Cytology and Embryology $\bullet$
Jagiellonian University $\bullet$ Grodzka $52 \bullet$ PL-31-044 Cracow $\bullet$ Poland $\bullet$ bartek78pl @ poczta.onet.pl
LUBOMír ADAMEC $\bullet$ Institute of Botany $\bullet$ Academy of Sciences of the Czech Republic $\bullet$ Section
of Plant Ecology $\bullet$ Dukelská $135 \bullet$ CZ-379 82 Třeboň $\bullet$ Czech Republic $\bullet$ adamec@ butbn.cas.cz

Keywords: physiology, taxonomy: Utricularia ochroleuca, U. stygia.

\section{Introduction}

Utricularia ochroleuca R. Hartm. is an amphibious/aquatic carnivorous plant occurring relatively rarely throughout Europe and North America in peat bogs and shallow standing dystrophic waters (Taylor 1989; Schlosser 2003). This species rarely flowers, is sterile, and is possibly of hybridogenic origin (i.e. $U$. minor $\times U$. intermedia; Thor 1988). Thor (1988) split this taxon into two species, U. ochroleuca s. str. and U. stygia Thor (see Figure 1), on the basis of minor differences in corolla morphology, the number of leaf teeth tipped with bristles, and, especially, in the structural details of the quadrifid (i.e. four-armed) $\times$-shaped glands (hairs) in their carnivorous traps. The rarity of flowering, the unreliability of the tooth number on the leaves as a determination marker, preventing from easy determination (the numbers greatly overlap; Thor 1988; Schlosser 2003), and the rarity of these two species in Central Europe contributed partly to the neglect or refusal of the Thor's concept of U. stygia as a separate species (in the Czech Republic e.g., Holub \& Procházka 2000; Adamec \& Lev 2002; Sirová et al. 2003). The strongest argument that $U$. ochroleuca s. str. and $U$. stygia are separate species hinges upon differences in their quadrifid glands. According to Thor (1988), U. ochroleuca s. str. has a very wide angle between the shorter arms of the glands (usually $146-197^{\circ}$, on average $171^{\circ}, 2 \mathrm{SD}=51^{\circ}$ ), while in $U$. stygia, the angle is much narrower (usually $52-97^{\circ}$, on average $74^{\circ}, 2$ SD $45^{\circ}$ ). Quadrifid glands (hairs) in Utricularia traps are known to be associated with carnivory. They secrete digestive enzymes and absorb released nutrients (e.g., Juniper et al. 1989; Sirová et al. 2003). Recently, cell wall ingrowths typical of "transfer cells" have been reported in $U$. intermedia quadrifid glands (Płachno \& Jankun 2004) demonstrating an intensive short-distance solute transport between the glands and the trap fluid.

However, in the last 5-10 years, $U$. stygia has been more widely accepted as a taxon distinguishable from $U$. ochroleuca s. str. Populations have been identified in several European countries in addition to Thor's (1988) original distribution in Scandinavian countries, Denmark, Scotland (Hackney 2000) and Germany. Zidorn (1996) found it in Austria (Tirolia), Tassara (2002) in N Italy, Wolff (1993) in E Germany, and Schlosser (2003) demonstrated its presence in SW Germany. It also occurs in NE Russia (Karelia) and France (Michaux 2002; Schlosser, pers. comm.). Additional discoveries are likely, and it can be expected that $U$. stygia has an even broader European spread than we currently know. In the Czech Republic, U. stygia has never been reported though it may occur there (Adamec \& Lev 2002). Utricularia ochroleuca s. lat. is a critically endangered species of the Czech flora (with only about fifteen sites) and the centre of its Czech distribution lies dominantly in Třeboň basin, S Bohemia (Holub \& Procházka 2000). In the 1990s, the number of its existing sites in this region was about twelve but some of these sites no longer exist (Adamec, unpubl.).

The aim of this study was to explore the occurrences and character variabilities in $U$. ochroleuca s. str. and $U$. stygia by studying $U$. ochroleuca s. lat. plants from all known existing sites (in 2003) in Třeboň basin, Czech Republic, by measuring size and geometric parameters of the quadrifid glands arms, and in this way, to look for $U$. stygia. The map of recent distribution of U. ochroleuca s. str. and U. stygia in the Czech Republic is also presented. 


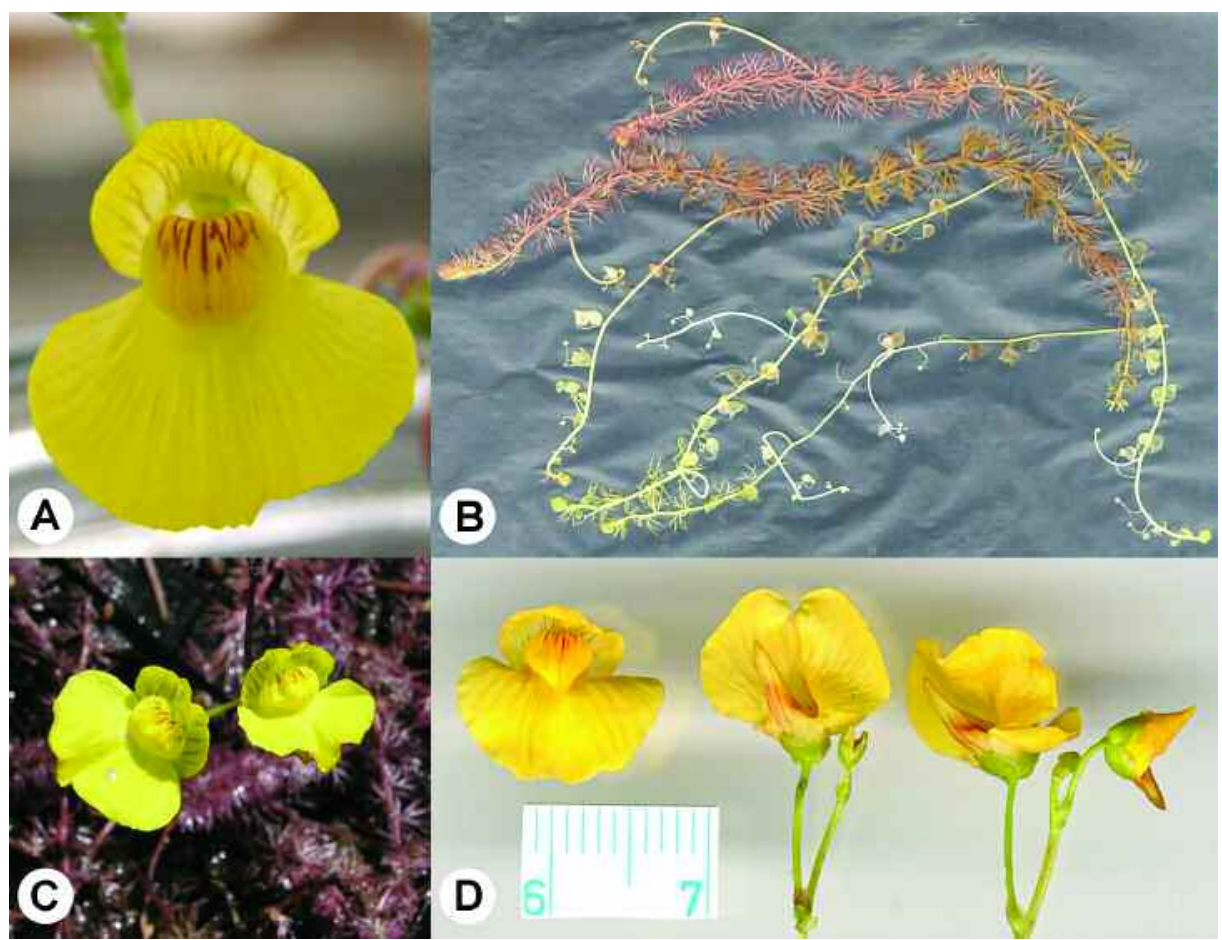

Figure 1: Left upper: Flower of Utricularia stygia growing in a floating aquarium in the outdoor culture of the Institute of Botany at Treboň, Czech Republic; May 2005. The plants originate from Švarcenberk. Right upper: Scanned shoots of $U$. stygia from Hlinír; May 2000. Left bottom: Flowering U. stygia in a very dense stand at Hlinír; June 2003. Photo by J. Flísek. Right bottom: Scanned flower of $U$. stygia from the outdoor culture; August 2003. The plants originate from Švarcenberk. Note reddish tinge of the corolla and relatively long spur. The other images by $\mathrm{L}$. Adamec.

Material and methods

On 6 August 2003, plants of U. ochroleuca s. lat. were collected from all previously known sites in the Třeboň Basin Biosphere Reserve and Protected Landscape Area, S Bohemia, Czech Republic (approx. $49^{\circ} \mathrm{N}, 14^{\circ} 45^{\prime} \mathrm{E} ; 425-450 \mathrm{~m}$ a.s.l.). The eight sites were in Ponědrážka, Hlinír, Švarcenberk, Ptačí blato, Rod, Naděje, Vizír, and Podsedek. The habitats were peat bogs, usually in the littorals of eutrophic fishponds (Adamec \& Lev 2002). Plants of U. ochroleuca s. lat. were found neither at Černiční fishpond nor in Františkov village (floodplain of the Dračice river). At Hlinír, the plants were collected from two different bog pools (proximal and distal) which were isolated by a $200 \mathrm{~m}$ wide band of forest. Shoot segments (usually colourless and leafless) of four to five different plants with mature traps were collected from each site and placed in small plastic vials. Analyses of quadrifid glands were performed one day after the plant collection. At Ponědrážka site, the peaty soil was almost dry and the plants were strikingly short, with only a few traps formed. In this case, the bladders of one plant were analysed while the other four plants were transferred to a small aquarium in an outdoor culture in the Institute of Botany at Třeboň. After mature traps had been formed in these plants the analysis of glands was performed on 8 September 2003.

One mature trap from each of four collected plants from each site was used for microscopic investigation of the glands. Quadrifid glands in longitudinally halved traps in water were photographed using a computer-controlled microscope camera Hitachi HV-20C (Hitachi Denshi. Ltd., Tokyo, Japan; software Lucia; Imaging Industry, Prague) at 200 magnification. Within each trap, relatively representative glands were imaged from an undamaged (usually central) part of 


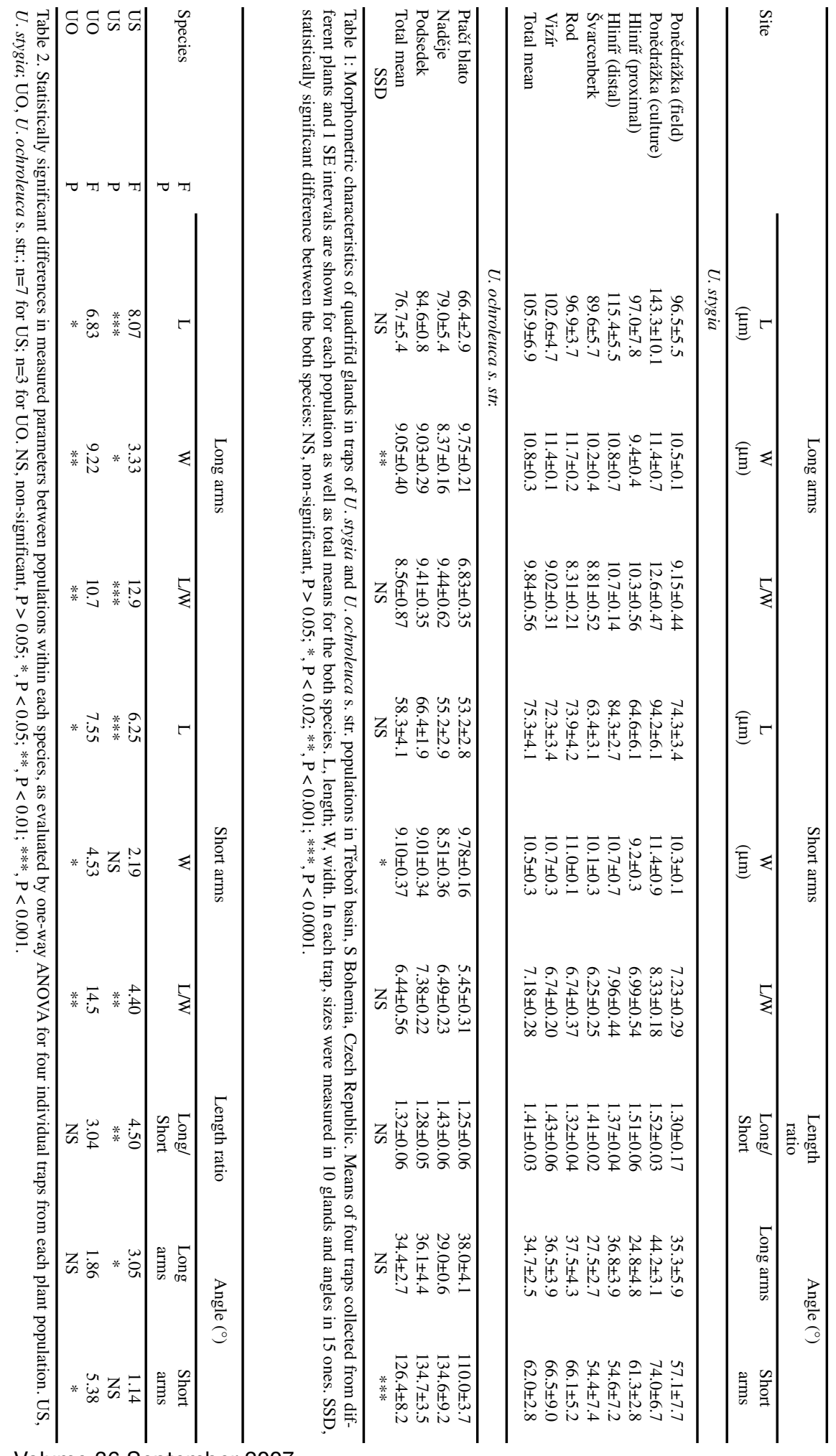




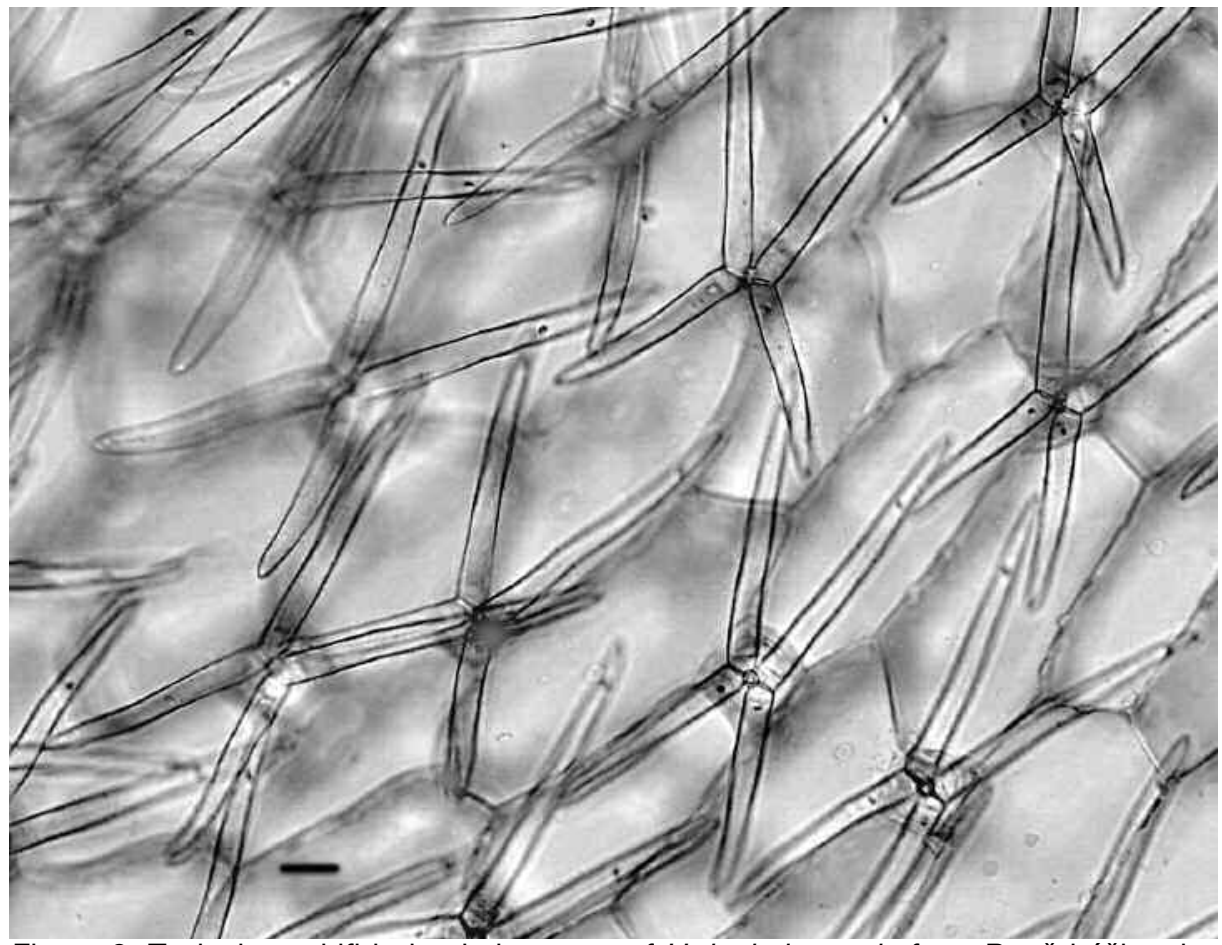

Figure 2: Typical quadrifid glands in a trap of Utricularia stygia from Ponědrážka site grown in outdoor culture. Black bar represents $20 \mu \mathrm{m}$.

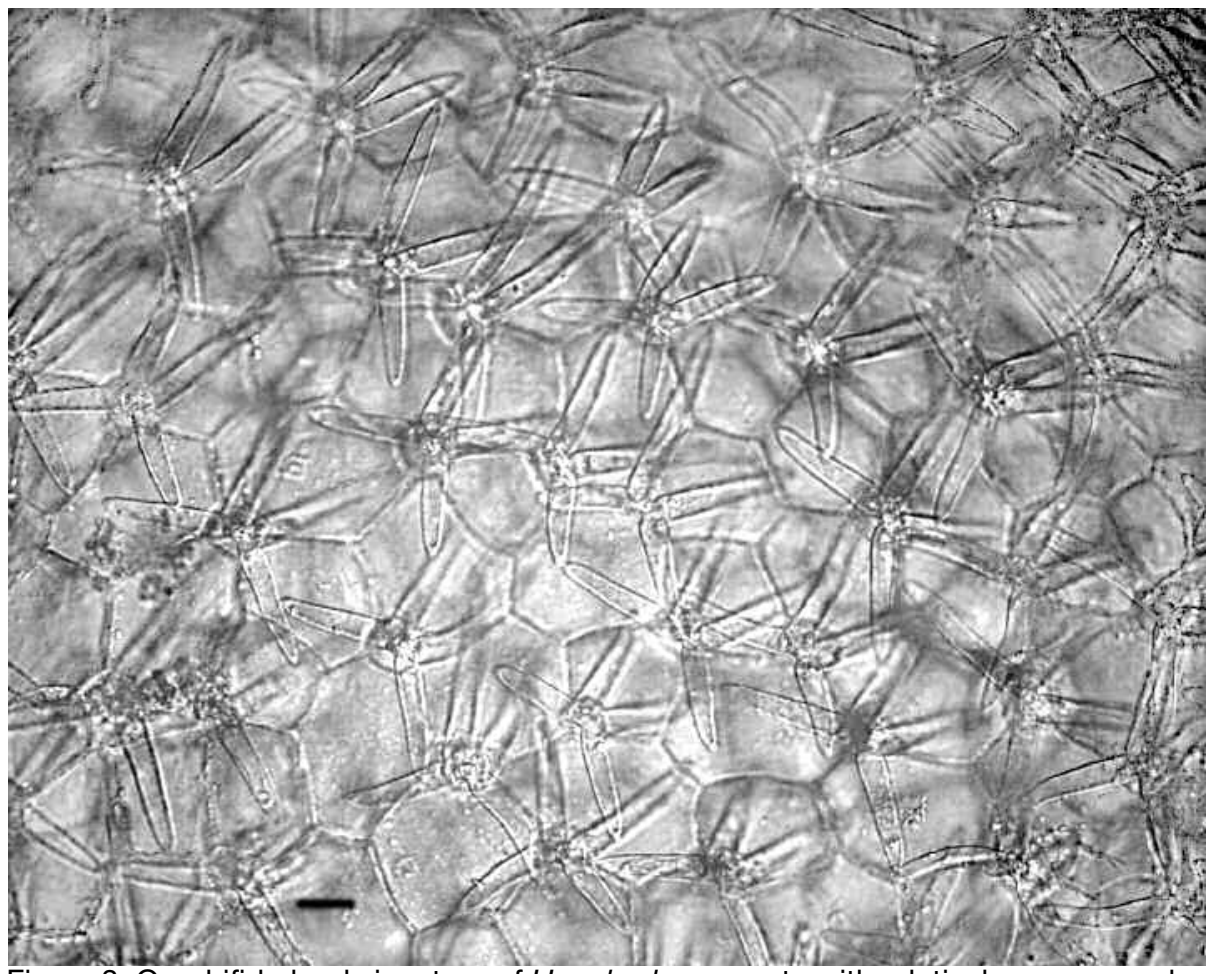

Figure 3: Quadrifid glands in a trap of $U$. ochroleuca s. str. with relatively narrow angles between the shorter arms collected from Ptačí blato site. Black bar represents $20 \mu \mathrm{m}$. 
the trap. One image per trap was printed, and the following parameters were measured using a ruler and a protractor: length (L) and maximum width (W) of both long and short arms and angles (to the nearest $0.5^{\circ}$ ) between the basal parts of long and also short arms (see Schlosser 2003). The sizes were measured in ten quadrifid glands (i.e., twenty values for each parameter), and angles were measured for fifteen glands. The glands that were imaged with the greatest clarity and sharpness were selected for these measurements to minimize geometric distortion of both sizes and angles. Mean values of all parameters from individual traps from each site were evaluated by one-way ANOVA (Tukey HSD test), both as within-species and between-species differences. Herbarium material of some examined specimens was deposited in the herbarium (KRA) of the Institute of Botany, the Jagiellonian University, Cracow, Poland.

\section{Results}

When all populations of the both Utricularia species were taken together, a within-species statistically significant difference at least at $\mathrm{p}<0.03$ was found in each of nine parameters estimated (Long arm L, long arm W, long arm L/W, short arm L, short arm W, short arm L/W, long arm L/short arm L, long arm angle, short arm angle; data not shown). Thus, it is reasonable to consider that the populations belong to two species. However, the size parameters of the quadrifid glands (especially lengths of long and short arms) were greatly variable even within each species, within and between populations (see Tables 1,2 ), and the only statistically significant difference at $\mathrm{p}<0.02$ between the two species was found in width of both long and short arms and in angle between the shorter arms $(\mathrm{p}<0.0001)$. Therefore, the angle between the shorter arms could be used as the only reliable criterion between the both species at a sterile state. In different populations determined as $U$. stygia, mean values of the angle ranged between $54-74^{\circ}$ and in single traps, the mean angle never exceeded $81^{\circ}$. Plants from Ponědrážka, Hlinír (both proximal and distal), Švarcenberk, Rod, and Vizír were determined as Utricularia stygia, in contrast with the plants from Ptačí blato, Naděje, and Podsedek, which were determined as U. ochroleuca s. str. (see Table 1; Figures 2-4). In the latter species in different populations, the mean angles between shorter arms ranged between $110-135^{\circ}$ and in single traps, the mean angle never fell below $101^{\circ}$. One-way ANOVA for individual traps revealed within-species statistically significant differences $(\mathrm{p}<0.05$ or better) for almost all measured parameters, except for the angles between short arms in U. stygia (see Table 2).

\section{Discussion}

The mean angles between the short arms of $U$. stygia from South Bohemia (Table $1 ; 54-74^{\circ}$ ) are well within the range $\left(74 \pm 22^{\circ}\right)$ given for this taxon by Thor (1988) and confirmed by Schlosser (2003). However, the mean angles between the short arms in $U$. ochroleuca s. str. from $\mathrm{S}$ Bohemia (Table $1 ; 110-135^{\circ}$ ) are not only much lower than mean typical Scandinavian plants but even somewhat lower than a minimum angle $\left(117^{\circ}\right)$ given by Thor (1988). But in the same paper, Thor noted that $U$. ochroleuca s. str. was a rather polymorphic species which probably might consist of some closely related taxa. In the European material, he distinguished two variants: typical one from Nordic countries, which he described in detail, and another variant which grows outside Scandinavia. This variant has smaller quadrifid glands (shorter long arms) and also a distinctly smaller angle between short arms than in the "Nordic" plants. U. ochroleuca s. str. from S Bohemia represent this second variant. However, in light of a great variability of morphological parameters and low number of statistically investigated world populations of $U$. ochroleuca s. lat., Thor's concept of $U$. stygia as a separate species might not be accepted. It would be also possible to accept $U$. ochroleuca s. lat. as one polymorphic species with the taxon $U$. stygia on the level of subspecies or variety. The main problem how to interpret these quantitative data on the angles for taxonomy is whether they are continuous or discontinuous on the European scale. Cytological and molecular studies (e.g., RAPD, DNA sequencing) of different populations could bring more light into this topic. Also, it might be useful to perform cross experiments between $U$. intermedia and $U$. minor and study the properties of the hybrids.

For practical determination reasons, it is possible to reliably distinguish between $U$. stygia 


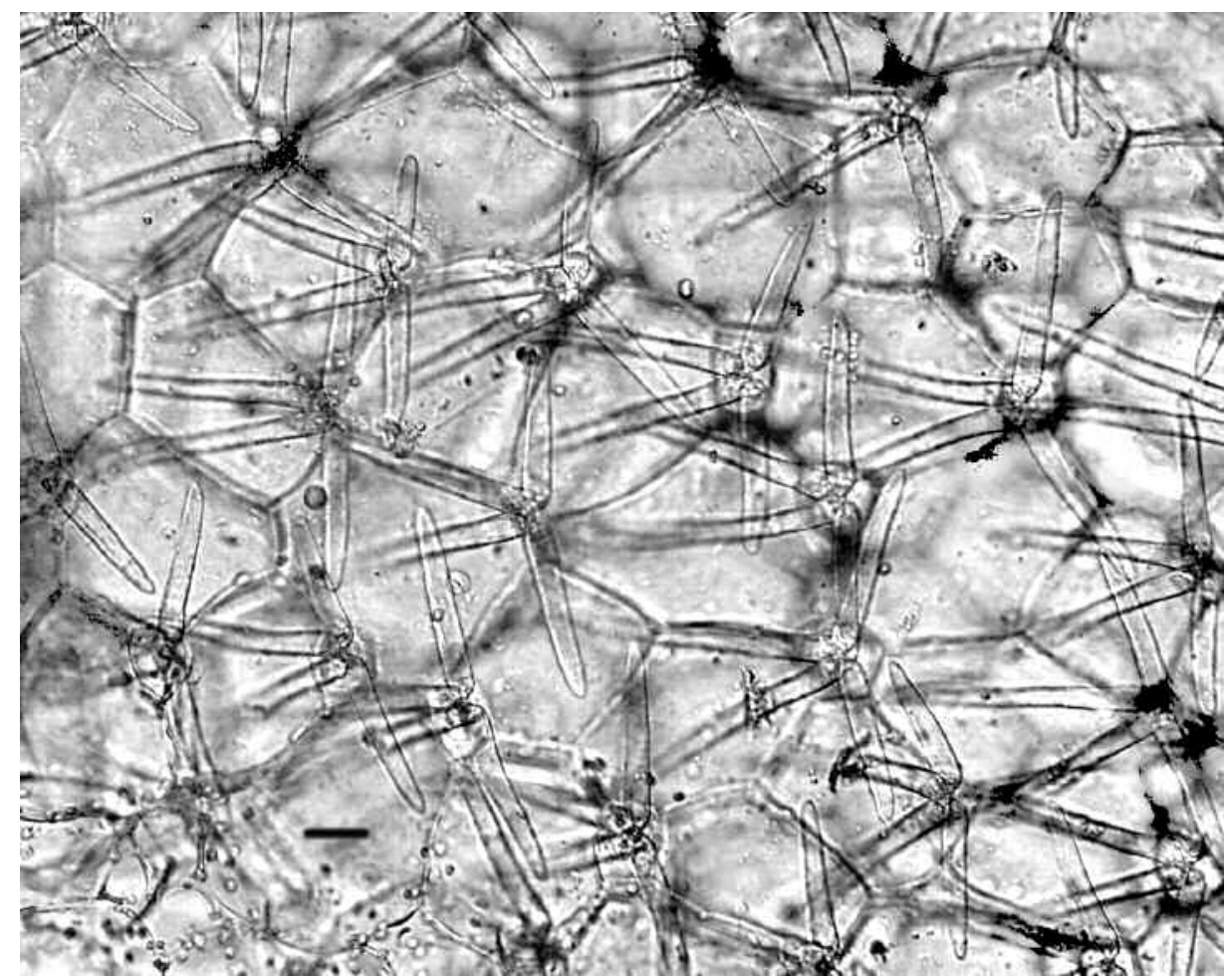

Figure 4: Typical quadrifid glands in a trap of $U$. ochroleuca s. str. with relatively wide angles between the shorter arms collected from Naděje site. Black bar represents 20 $\mu \mathrm{m}$.

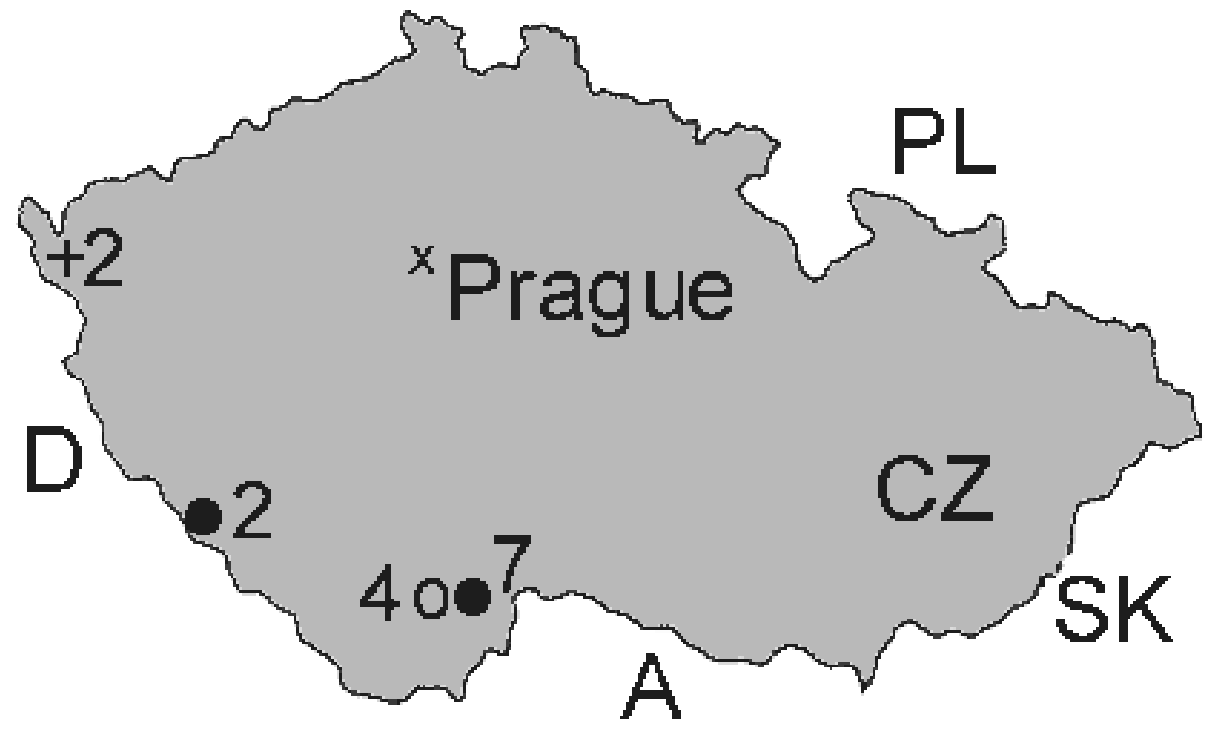

Figure 5: The map of recent (2005) natural distribution of $U$. ochroleuca s. lato (crosses), U. ochroleuca s. str. (empty circles), and of $U$. stygia (full circles) in the Czech Republic. For each region and species, the number denotes the number of recent natural sites. 
and $U$. ochroleuca s. str. by applying the following criteria for the plants from the Třeboň Basin and/or the Czech Republic (see also Figures 2-4):

Utricularia stygia: the mean angle between the shorter arms is always below $85^{\circ}$ but the maximum angle below $115^{\circ}$.

Utricularia ochroleuca s. str.: the mean angle between the shorter arms is always above $100^{\circ}$, the minimum angle can also be only $70^{\circ}$ but there are always maximum angles (at least in $10 \%$ of glands) above $120^{\circ}$ and usually above $130^{\circ}$.

We observed a great variability of the size parameters of the arms and angles between arms in traps of the both studied species, on the level of both within-population and between-population. It is necessary to emphasize that the same great variability of the angles between shorter arms exists also within single traps. The situation is clear in $U$. stygia traps with relatively low variation (see Tables 1, 2; Figure 2). However, as found in traps of $U$. ochroleuca s. str. there are small patches of quadrifid glands with the angles reminding U. stygia (see Figure 3). For a reliable determination, it is therefore necessary to investigate as many glands as possible (at least 40-50) within each trap and focus mainly on the above maximum angles. Moreover, to inspect at least five traps.

The great within-population variability could reflect a great variability of microhabitat factors (e.g., water level, oxygen concentration, temperature, prey availability, etc.), some of which could influence gland development. In our study, there was a great quantitative difference in parameters between field-collected U. stygia plants from Ponědrážka site and those grown in outdoor culture (Table 1). Taylor (1989) noted also a great variation in Utricularia quadrifid glands in the same trap, between traps on the same plant, and between plants from different populations.

According to Thor (1988), the both species also differ slightly in the color and shape of corolla. Utricularia ochroleuca s. str. has light yellow corolla with its lower lip almost flat or downwards deflexed margins and spur length is only about $3 \mathrm{~mm}$. Whereas $U$. stygia has yellow corolla with a reddish tinge and lower lip is flat or slightly curved upwards; spur length is 4-5 $\mathrm{mm}$. At some investigated sites (Hlinír and Vizír) at which we had determined U. stygia using the angles of the arms, we later found flowers which corresponded to the taxon of U. stygia. They reminded those in the Institute's culture (see Figure 1, collected from Švarcenberk) and were dark yellow with red ribs and 4-5 mm long spur.

According to Taylor (1989), U. ochroleuca s. lat. is not one but several morphologically slightly different clones which reproduce only vegetatively and might have different chromosome numbers. Schlosser (2003) showed that also populations of U. ochroleuca from North America (which he described as $U$. ochroleuca s. lat.) were very different from each other and also different from typical Scandinavian $U$. ochroleuca s. str. Summarily, the complex $U$. ochroleuca-U. stygia probably consists of sterile hybrids which have different mother plants $(U$. minor or $U$. intermedia) and originated at different time and places. Differences between Scandinavian and Central European populations of $U$. ochroleuca might be connected also with glaciations. "Nordic" U. ochroleuca s. str. might be a young taxon which has spread on a deglaciated area over Scandinavian Peninsula. It should be added that also Schlosser (2003) considered southern populations as evolutionary old.

Utricularia stygia has a wide circumboreal distribution in the northern hemisphere. According to Schlosser (2003), this species is more common than U. ochroleuca s. str. in Europe and probably also in North America. Our results fully agree with his suggestion. In Třeboň basin in S Bohemia, U. stygia has been verified recently (2005) to have seven natural sites (and one artificial) whereas $U$. ochroleuca s. str. only four sites. In the whole Czech Republic, $U$. ochroleuca s. lato has two other sites in W Bohemia and so has also U. stygia in SW Bohemia (see Figure 5; Adamec, unpubl.). Moreover, there is a great difference in the size of the popula- 
tions of both species. While all $U$. stygia populations investigated are usually within the order of magnitude of thousands to hundreds of thousands of shoot apices those of U. ochroleuca s. str. have only dozens or a few hundred shoot apices (Adamec, unpubl.) and may be characterized as vanishing. However, both species are rare and threatened with extinction in the Czech Republic.

Nevertheless, $U$. stygia behaves as a stronger competitor than $U$. ochroleuca s. str. as it can be judged from the fact of natural spreading of the former species to a previous $U$. intermedia site at Ruda peat bog (Navrátilová \& Adamec, unpubl.). Moreover, in contrast to U. australis, they both have a narrow ecological range and meet specific habitat requirements. In S Bohemia, they grow in peat bogs, usually in the littorals of eutrophic fishponds (Adamec \& Lev 2002), and these shallow dystrophic and oligo-mesotrophic waters are very sensitive to eutrophication, overgrowing, and drainage. According to Thor (1988), in Nordic countries $U$. stygia grows only in oligotrophic habitats; in stagnant, shallow waters in wetlands and peat bogs, while $U$. ochroleu$c a$ s. str. grows usually in slightly eutrophic and semi-rich habitats. In S Bohemia, there is evidently no habitat segregation between the species.

Conservation measures should consist of protection of habitat and its sustainable development. In addition, the propagation of the plants ex situ and their subsequent (re)introduction to old natural and new sites within the same area are recommended. The first step has been made because both South Bohemian $U$. stygia and U. ochroleuca s. str. have been successfully cultivated in the outdoor Collection of Aquatic and Wetland Plants in the Institute of Botany at Třeboň. Cytological-anatomical studies on South Bohemian U. stygia have also been started (Płachno et al., 2005). Search for seeds and embryological study of both species, such as in $U$. bremii, could be beneficial as fertile plants producing seeds could be found in some populations (Adamec 2002).

\section{Acknowledgements}

This study was supported partly (to L. A.) by the Research Programmes of the Academy of Sciences of the Czech Republic (Nos. AV0Z6005908, AV0Z60050516 and KSK6005114). Sincere thanks are due to Prof. Douglas W. Darnowski (Indiana Univ., New Albany, USA) for linguistic correction and to Dr. Barry Rice (University of California, Davis, CA, USA) for correction of the text. This study was performed on the basis of the permit of the Ministry of Environment of the Czech Rep. No. OOP/3724/01.

\section{References}

Adamec, L., 2002. News and Views. Carniv. Pl. Newslett., 31: 19.

Adamec, L., and Lev, J. 2002. Ecological differences between Utricularia ochroleuca and $U$. intermedia habitats. Carniv. Pl. Newslett., 31: 14-18.

Hackney, P. 2000. Flora of Northern Ireland, http://www.habitas.org.uk/flora, accessed May 2006.

Holub, J., and Procházka, F. 2000. Red list of vascular plants of the Czech Republic-2000. Preslia, 72: 187-230.

Juniper, B.E., Robins, R.J., and Joel, D.M. 1989. The Carnivorous Plants. Academic Press, London, UK.

Michaux, J. 2002.http://crdp.ac-besancon.fr/flore/flore/Lentibulariaceae/especes/utricularia_stygia.htm, accessed May 2006.

Płachno, J.B., and Jankun, A. 2004. Transfer cell wall architecture in secretory hairs of Utricularia intermedia traps., Acta Biol. Cracov. Ser. Bot., 46: 193-200.

Płachno, J.B., Jankun, A., and Faber, J. 2005. Development of the wall labyrinth in pavement epithelium hairs of some Utricularia species. Acta Biol. Cracov. Ser. Bot., 47: 109-113.

Schlosser, E. 2003. Utricularia stygia in California, USA, and U. ochroleuca at its southern range. Carniv. Pl. Newslett., 32: 113-121.

Sirová, D., Adamec, L., and Vrba, J. 2003. Enzymatic activities in traps of four aquatic species of the carnivorous genus Utricularia. New Phytol., 159: 669-675.

Tassara, F. 2002. Primo rinvenimento di Utricularia stygia Thor (Lentibulariaceae) in Italia e suo 
confronto con precedenti segnalazioni di Utricularia ochroleuca Hartman. Gredleriana, 2: 263-270.

Taylor, P. 1989. The Genus Utricularia-A Taxonomic Monograph. Kew Bulletin Additional

Series XIV, London, UK.

Thor, G. 1988. The genus Utricularia in the Nordic countries, with special emphasis on $U$. stygia and U. ochroleuca. Nord. J. Bot., 8: 213-225.

Wolff, P. 1993. In (Lang, W., ed.): Flora der Pfalz. Verbreitungsatlas der Farn- und Blütenpflanzen. Veröff. Pfälz. Ges. Förd. Wiss. Speyer 85: 40.

Zidorn, C.H.W. 1996. Erstnachweis von Utricularia stygia Thor in Österreich. Ber. Nat.-Med. Verein Innsbruck, 83: 331-334.

PHONE: 61 (0)3 97691663,10 am to 5pm Monday to Thursday ONLY
FAX: $61(0) 397015816,24$ hours, 7 days per week
WEB: www.triffidpark.com.au
EMAIL: triffids @ triffidpark.com.au
Managed by Donna ClaytonSmith.
Fwned and operated by Colin and Tina Clayton.
FOR ALL YOUR CARNIVOROUS PLANT REQUIREMENTS INCLUDING:
PLANTS, POTS, LABELS, BOOKS, SEEDS, SPHAGNUM MOSS AND PEAT MOSS
WRITE, PHONE, FAX OR EMAIL TRIFFID PARK FOR A FREE COLOR
MAIL ORDER CATALOGUE OR VIEW OUR COMPREHENSIVE WEB SITE.
You are most welcome to visit Triffid Park but please organise this with us first,
as inspection is by appointment ONLY.

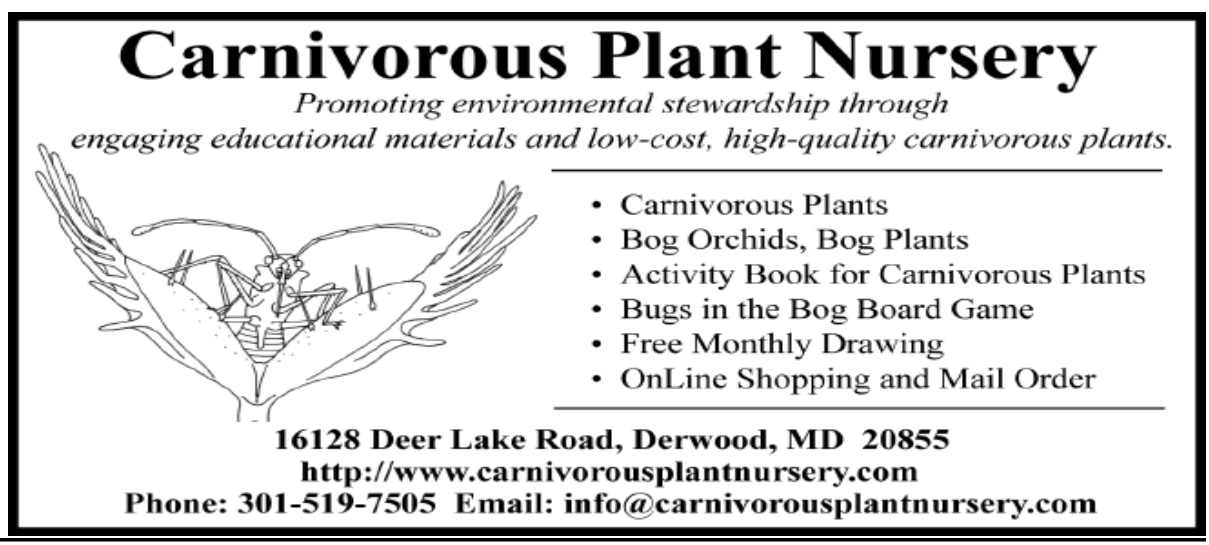

\section{Carolina Carnivorous Gardens}

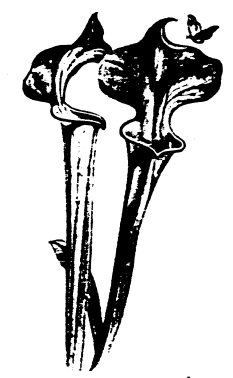

"Specializing in insect eating plants"

$\star$ on site sales \& display gardens

$\star$ call ahead for appointment

$\star$ U.N.C.C. Sarracenia hybrids

$\star$ winter hardy Drosera species

$\star$ plants commercially propagated

1509 Little Rock Road Charlotte, NC 28214

Phone: 704-399-3045 Cell: 704-458-8538

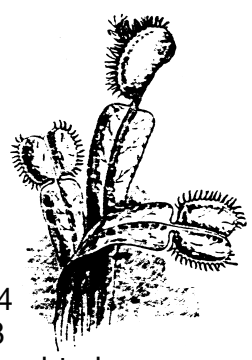

http://personal.atl.bellsouth.net/clt/f/l/flytrap1/index.html

Contact: DAVID CRUMP

Price list - S.A.S.E. 